\section{Knockabout stuff}

\section{Derek Ager}

The Tenth Muse: The Pursuit of Earth Science. By Ronald B. Parker. Charles Scribner's Sons: 1986. Pp. 221. \$15.95.

THE nine official muses were responsible for literature, art and a limited amount of science. They had originally been three in number, but six more were conceived and so it is reasonable to add another to represent geology, the most beautiful and inspiring of the sciences. Professor Parker, however, obviously nominates the subject for its entertainment value rather than for its aesthetic qualities.

We are all interested chiefly in our own ideas, but Professor Parker's egocentricity is particularly evident. He assumes that we have read his previous book, and tells us how his great "buffer" idea came to him and how the audience reacted to it at various lectures. Personally I do not understand the "buffer" terminology which is central to most of Dr Parker's thoughts, and would have thought that a better metaphor for what he discusses (the storage and sudden release of energy) would have been the elastic band, which can be stretched so far before suddenly breaking.

Parker's main interest is in our geological today and yesterday - geysers and landslips, glaciers and ice dams. In "The Urge to Surge", for example, he discusses the movement of glaciers and their episodic behaviour, making an assignation with the reader up in Alaska around the year 2000 when things are due to get moving again.

In an excursion into his other main field, crystallography, Parker points out that this science originated in the West, where symmetry is taken for granted, and not in the East where the Zen philosophy prefers asymmetry, be it in gardens or pottery. He goes on to discuss man and other "non-crystallographic" forms in the world (with a delightful independence of thought, he and his wife built themselves a 14-sided house), and Schechtman's discovery of the impossible, that is to say, five-fold symmetry in crystals, as a salutary warning of the need for his own kind of open-mindedness. As a palaeontologist I should point out that echinoderms came up with five-fold symmetry first, albeit using trigonal calcite crystals.

There is a boyhood trip to Boron, site of the largest borate mine in the world, before an essay on "coral clocks" and organic growth generally. Here Parker regrets that corals, with their daily growth-lines, are rare as fossils compared with "clams", thereby displaying a surprising ignorance of the Palaeozoic part of the record. He obviously prefers the "clams" (including their suitability for feeding the poor gra- duate students studying them), and shocks the palaeontologist by referring to the brachiopods as their "look-alikes". All of this makes me prefer Parker as a geomorphologist and crystallographer rather than as a palaeontologist-stratigrapher.

So we go on to "Aqua Spectaculars and Other Disasters", ranging from Esther Williams and her symmetrical swimmers in those boring films of the $1930 \mathrm{~s}$, and via an extremely tenuous link to tsunamis and catastrophically emptying lakes, such as Lake Bonneville and, of course, J. Harlen Bretz's spectacular Lake Missoula. And so back to the "buffer" phenomenon (or better perhaps the knicker elastic of the same vintage as Professor Parker's films) in the building and release of energy in eruptions ranging from Mount St Helen's to Santorini.

There is, too, a general discussion of fossil "scat" (excreta to British readers), including description of a remarkable con-

\section{Wilder shores}

\section{Peter J. Smith}

Islands. By H. W. Menard. W. H. Freeman:1986. Pp.230. £15.95. In the United States available only to members of the Scientific American Library.

THERE seem to be as many books called Islands as there are islands, concentrating on everything from scenery, through seafaring and survival, to science. Menard's version falls into the last category, as one might expect from a distinguished geological oceanographer who ended up as Director of the US Geological Survey. But a scientific book on islands sounds a bit like one on kidneys; one can see the attraction of specialization whilst taking leave to doubt whether much sense can be made of the parts in isolation from the body as a whole. As far as the Earth sciences are concerned, the revolution of the $1960 \mathrm{~s}$, which produced the first convincing global theory of the Earth's behaviour, placed islands firmly in the context of spreading sea-floors and jostling tectonic plates, from which conjunction they are never likely to escape.

Inevitably, therefore, Menard has ended up writing a book largely about plate tectonic processes, albeit with islands taking centre stage and with little mention of continents. Excluded too, incidentally, are those islands, large or small, with a continental structure (Britain, New Zealand, Japan, the Seychelles, certain Indonesian islands and so on). Menard's islands are oceanic - volcanic or volcanic/ coral, "small, young, isolated, simple, and subjected to a limited range of environmental factors". In geological terms they represent the closest that nature comes to centration of three billion tons of apatite in the Kola Peninsula which might have been the result of a monstrous ball of dung hitting the Earth. More seriously, we are told that from the evidence of their "scat" the giant ground sloths may have become extinct from a drug overdose, through eating the plant known as "Mormon tea". So the book goes on, leaping nimbly from one unlikely topic to another - remote sensing to salt "punch-ups", karst erosion to mass extinctions, until finally reaching the geological glory of field-work in (where else for a muse?) the Elysian Fields.

This is an enjoyable book, a cheerful somersault rather than a solemn symposium and better for entertainment than for education. But that, presumably, was the author's intention.

Derek Ager is Research Professor in the Department of Geology, University College of Swansea, Swansea SA2 $8 P P, U K$.

laboratory conditions, with dependent variables at a minimum.

Notwithstanding the restricted definition, there is a surprising amount to say. For one thing, islands are perpetually under the influence of spreading lithosphere and stationary hot spots, and all that means in terms of aging, subsidence, rates of extrusion, distribution, redistribution and, ultimately, subduction, continental underplating or terrane formation. New volcanic masses lead to isostatic adjustments and lithospheric warping, the effects of which can be obscured by multicausal changes in sea level. Then there is the whole phenomenology of underwater volcano formation and decay, involving magma flow, growth rates, erosion and submergence, with or without the participation of coral. Finally, the issue of colonization raises important questions about evolution, migration and civilization.

Plate tectonics though much of this may be in essence, it is plate tectonics viewed obliquely. It does no harm at all to be forced to look at familiar concepts from an unusual angle as long as the viewpoint is coherent, which is Menard's hands it certainly is. The level could best be described as Scientific American, which means that the absolute novice may find it tough going in parts. Those with a smattering of basic terminology, however, will discover a rewarding and unusually enjoyable volume, not at all a bad memorial to an Earth scientist who was ever ready to look beyond his immediate research.

Peter J. Smith is Reader in Earth Sciences at the Open University, Walton Hall, Milton Keynes $M K 76 A A, U K$.

- Another of Henry Menard's books to be published posthumously, The Ocean of Truth: A Personal History of Global Tectonics (Princeton University Press), will be reviewed in a future issue of Nature. 